\title{
PENGLIBATAN SUAMI DALAM KERJA-KERJA RUMAH TANGGA: KAJIAN KES DI SABAH
}

\section{Husband's Involvement in the Household Chores: A Case Study in Sabah}

\author{
Siti Halimah Putung * \\ Dg Hafizah Ag Basir **
}

\begin{abstract}
Today, women's labor is needed not only in a home but is also needed outside the house. The change in women's role from the private sphere to the public sphere does not reduce or change their traditional roles and responsibilities. Religious teachings and traditional customs are the biggest influences to women being obliged to do household chores despite having their own careers. This has become the major challenge for the women in dividing their duties at work and at home. They have to bear the burden of having too much household chores and not having enough time to carry them out. Due to this, the support and cooperation from the husbands are crucial in helping to balance the roles and duties of the wives. Therefore, this article identifies the needs for the husbands to get involved in the domestic
\end{abstract}

* Lecturer, Centre for the Promotion of Knowledge and Language Learning, Universiti Malaysia Sabah Labuan International Campus, ct_ha5h@ums.edu.my

** Lecturer, Centre for the Promotion of Knowledge and Language Learning, Universiti Malaysia Sabah,dhafizah@ums.edu.my 
household chores. Interviews and document analysis are used in this study. The results showed that the need for husbands to get involved in the household chores is crucial.

Keywords: Obligation, Household Chores, Career Women, Husband, Wife, Islam

\section{PENDAHULUAN}

Umumnya pekerjaan dapat dibahagikan kepada tiga jenis iaitu; kerja berupah (paid work), kerja paksaan (coerced work) dan kerja tidak berupah (unpaid work). Kerja-kerja rumah tangga tergolong dalam jenis kerja yang ketiga iaitu kerja tidak berupah yang dilakukan secara sukarela untuk diri sendiri dan orang lain. Kerjakerja rumah tangga merujuk kepada kerja-kerja yang dilakukan di dalam atau di sekitar rumah untuk diri sendiri atau untuk ahli keluarga. Ini termasuklah mencuci kereta, mencuci pakaian, mengemas rumah, memasak untuk ahli keluarga dan sebagainya. ${ }^{1}$

Secara tradisi, kaum lelaki dan kaum perempuan memegang peranan yang berbeza dalam agihan tugasan kerja rumah. Lazimnya, tugas dan tanggungjawab lelaki di luar rumah mencari nafkah dan pendapatan keluarga. Sementara, tugas wanita adalah bekerja di dalam rumah bagi menjaga hal ehwal rumah, anak dan suami. Bagaimana pun, peranan wanita hari ini pula telah mengalami perubahan dari rumah ke ruang pekerjaan.Tenaga wanita tidak hanya diperlukan di rumah bahkan di luar rumah. Penglibatan wanita dalam pasaran buruh selari dengan perubahan sektor ekonomi negara. Dekad 1980 dianggap dekad yang membuka pelbagai peluang pekerjaan kepada wanita. ${ }^{2}$ Kini kadar penyertaan tenaga kerja wanita terus meningkat daripada $46.8 \%$

Tan Jo-Pei, Rojanah Kahar, Hanina Halimatussaadiah Hamsan, "Keluarga dan Pekerjaan", dalam Pengantar Keluarga dan Perkahwinan, ed. Rozumah Baharudin, Rumaya Juhari (Selangor: Penerbit Universiti Putra Malaysia, 2002), 158.

2 Nor Aini Idris, Wanita dan Pembangunan Ekonomi (Kuala Lumpur: Dewan Bahasa dan Pustaka, 2008), 28. 
pada tahun 2010 kepada 55\% pada tahun 2015 dan dijangka terus meningkat pada tahun $2020 .^{3}$

Perubahan yang dialami oleh kaum wanita ini tidak mengurangkan atau mengubah tanggungjawab dan peranan tradisi mereka. Agama Islam dan tradisi Melayu memberi pengaruh besar kepada wanita Melayu melakukan kerja-kerja rumah meskipun mereka bekerja. ${ }^{4}$ Beban kerja berganda ini dilihat sebagai salah satu bentuk ketidakadilan kepada wanita yang dikaitkan dengan agama. ${ }^{5}$ Wanita bekerja terpaksa menggabungkan peranan tradisi sebagai isteri dan ibu dengan peranan sebagai pekerja. Kerjakerja rumah bagi isteri bekerja ibarat shift kedua setelah penat seharian bekerja. Hal ini menjadi cabaran besar kepada wanita dalam membahagikan tugas mereka di tempat kerja dan di rumah. Wanita bekerja menghadapi masalah dalam melakukan tugasan di rumah dan di tempat kerja. Mereka terpaksa memikul beban kerja yang banyak di rumah dan tidak mempunyai masa yang cukup untuk melakukan semua kerja yang banyak di rumah serta tidak mempunyai masa yang cukup untuk melakukan semua kerja dalam satu masa termasuk menjaga anak-anak. ${ }^{6}$ Justeru wanita memerlukan pelbagai sistem sokongan individu terutamanya suami bagi menjayakan kedua-dua tanggungjawab ini secara seimbang dan berkesan. ${ }^{7}$

3 Rancangan Malaysia Kesebelas (http://epu.gov.my/sites/default/ files/Bab\%205.pdf)

4 Roziah Omar, "Negotiating Their Visibility: The Lives of Educated and Married Malay Women", dalam Women in Malaysia, ed. Roziah Omar, Azizan Hamzah (Kuala Lumpur: Utusan Publication and Distributor Sdn.Bhd, 2003), 128.

5 Mohd Anuar Ramli, "Analisis Gender dalam Hukum Islam”, Jurnal Fiqh 9 (2012), 137-162.

6 Noor Rahamah Abu Bakar, "Wanita Bekerja dan Pengurusan Keluarga", Journal of Society and Space 8 (2012), 155-162.

7 Mohd Ismail Mustari, Bushrah Basiron, "Faktor Sokongan Individu Terhadap Kecemerlangan Wanita Bekerjaya dan Berumah Tangga", Jurnal Teknologi (Social Sciences) (Johor: UTM Press, 2014), 5-16. 


\section{OBJEKTIF KAJIAN}

Secara umunya artikel ini bertujuan mengkaji penglibatan suami dalam kerja-kerja rumah tangga. Secara spesifiknya kajian ini mempunyai dua objektif iaitu; mengenal pasti keperluan suami melibatkan diri dalam kerja-kerja rumah tangga dan menjelaskan pandangan Islam mengenai penglibatan suami dalam kerja-kerja rumah tangga.

\section{KAEDAH KAJIAN}

Bagi mendapatkan maklumat mengenai penglibatan suami dalam kerja-kerja rumah tangga, kaedah temu bual berstruktur dan separa berstruktur kepada lapan orang isteri bekerja dijalankan. Menurut Hesse-Biber (2007), ${ }^{8}$ penyelidik boleh mendapatkan maklumat lebih peribadi daripada responden kajian, terutamanya berkaitan dengan kehidupan peribadi mereka, dan juga boleh memahami dengan lebih mendalam tentang pengalaman responden dengan menggunakan kaedah ini. Pemilihan responden berdasarkan ciri dan kriteria tertentu iaitu; suami isteri yang bekerja, usia perkahwinan lima tahun ke atas, memiliki sekurang-kurangnya seorang anak, tidak tinggal bersama ibu bapa, mertua atau ahli keluarga yang lain serta tidak mempunyai pembantu rumah.

Bagi mendapatkan pandangan Islam mengenai penglibatan suami dalam kerja-kerja rumah tangga kitab-kitab fiqh terutamanya kitab mazhab empat yang muktabar dan kitab-kitab hadis dirujuk bagi mendapatkan pandangan yang berautoriti dalam Islam.

Hesse-Biber, S.N., "The Practise of Feminist In-depth Interviewing", dalam Feminist Research Practise, ed. S. J. N Hesse-Biber, P. L. Leavy (California: SAGE Publications, 2007), 117. 


\section{TINJAUAN LITERATUR}

Kajian-kajian lepas Fatimah $(1985)^{9}$, Roziah $(2003)^{10}$, Noor Rahamah (2012) ${ }^{11}$, melaporkan wanita bekerja menghadapi masalah mengurus rumah tangga kerana kesuntukan masa dan beban kerja yang banyak. Untuk menghadapi cabaran ini, wanita menggunakan pelbagai strategi termasuklah mengagihkan tugasan kepada orang lain seperti menggaji pembantu rumah, mengupah orang lain pada waktu tertentu, mendapatkan bantuan suami dan anak-anak. Bagaimanapun kajian Sultana dan Zanariah (2011), ${ }^{12}$ Shuhairimi dan Huzili (2012) $)^{13}$ mendapati wanita bekerja yang tidak menggunakan khidmat pembantu rumah dalam melakukan kerja-kerja rumah tangga masih menghadapi masalah mengurus rumah tangga meskipun mendapat bantuan suami.

Kajian-kajian ini memperlihatkan peranan dan penglibatan suami dalam kerja-kerja rumah tangga menjadi penting apabila wanita mula keluar bekerja. Kajian-kajian antarabangsa mengenai peranan dan penglibatan suami dalam kerja-kerja rumah tangga

Fatimah Abdullah, "Wanita dan Pekerjaan: Satu Analisis Konflik Peranan," Akademia (1985), 77-93.

10 Roziah Omar, "Negotiating Their Visibility".

11 Noor Rahamah Abu Bakar, "Wanita Bekerja dan Pengurusan Keluarga".

12 A.M Sultana, Zanariah Noor, "Gender Perspektive of Working Mothers Challenging in Their Family", Australian Journal of Basic and Applied Sciences (2011), 727-731

13 Shuhairimi Abdullah, Huzili Hussin, "Ekspetasi Antara Hasrat dan Realiti Wanita bekerjaya Terhadap Pengurusan Kekeluargaan: Kajian di Universiti Malaysia Perlis", Journal of Human Development and Communication 1 (2012), 107-127. 
ini telah banyak dijalankan antaranya Dana dan William (1986) ${ }^{14}$, Carolyn et.al (1978) ${ }^{15}$, Adam et.al (2013). ${ }^{16}$

Dalam konteks Malaysia, kajian mengenai peranan suami dalam rumahtangga masih kurang dijalankan. Kajian-kajian lebih tertumpu kepada peranan bapa dalam perkembangan anakanak khususnya dalam membentuk tingkahlaku, sahsiah dan kecemerlangan akademik anak-anak antaranya kajian Rozumah dan Nazli (1999) ${ }^{17}$, Amla et.al (2010) ${ }^{18}$.

Bagaimanapun telah ada kajian mengenai penglibatan suami dalam kerja-kerja rumah tangga. Kajian Zuraini, et.al (2016) ${ }^{19}$ terhadap 10 orang suami di sekitar Kuala Lumpur dan Selangor mendapati suami lebih terbuka membantu isteri melakukan kerjakerja rumah tangga, faktor kesedaran suami mengenai keperluan isteri bekerja dan pengaruh agama Islam, dikaitkan dengan penglibatan suami dalam kerja-kerja rumah tangga. Namun begitu pandangan Islam mengenai penglibatan suami dalam kerjakerja rumah tangga tidak dibincangkan dalam kajian ini, selain menggunakan sampel kajian yang kecil dan lokasi berbeza yang

14 Dana V. Hiller, William W. Philliber, "The Division of Labor in Contemporary Marriage: Expectations, Perceptions and Perfomance", Social Problem 33(3), (1986).

15 Carolyn C. Perrucci, Harry R. Potter, and Deborah L. Rhoads. "Determinants of Male Family-Role Performance", Psychology of Women Quarterly 3 (1978)

16 Adam M.Galovan et.al, "Father Involvement, Father-Child Relationship Quality and Satisfaction with Family Work: Actor and Partner Influences on Marital Quality", Journal of Family Issues (2013).

17 Rozumah Baharudin \& Nazli@Nazlina Maliki, "Kebapaan dan Pencapaian Akademik Kanak-kanak Bandar dan Luar Bandar", Jurnal Pendidik dan Pendidik (1999), 61-83.

18 Amla Salleh, Zahara Aziz, Zuria Mahmud, Abd. Aziz Mahyuddin, "Peranan Bapa dalam Pembangunan Sahsiah Remaja dan Implikasinya terhadap Nilai Kekeluargaan", Jurnal Pendidikan Malaysia 35(2), (2010), 9-17.

19 Zuraini Jamil, et.al, “Men's Involvement in the Domestic Sphere: A Study of Malay Muslim Men in Dual-Career Families in Kuala Lumpur and Selangor", Proceedings for the International Conference on Education Islamic Studies and Social Sciences Research (2016), Aceh, Indonesia. 
berkemungkinan menyumbang kepada dapatan yang berbeza dengan kajian yang difokuskan.

Sementara kajian Roziah (2003) ${ }^{20}$ pula, mendapati adat dan agama memberi pengaruh kepada wanita Melayu yang bekerja untuk tetap melakukan kerja-kerja rumah tangga. Ini menunjukkan pengaruh agama Islam telah membentuk sikap suami yang lebih terbuka dan isteri yang lebih tradisi dalam melakukan kerja-kerja rumah tangga. Oleh yang demikian, situasi yang kontradik ini menjustifikasikan penjelasan Islam mengenai tanggungjawab melakukan kerja-kerja rumah tangga, agar tidak berlaku kekeliruan.

\section{HAK DAN KEWAJIPAN SUAMI DAN ISTERI DALAM PERKAHWINAN}

Perkahwinan adalah satu tanggungjawab dan amanah yang harus dipikul oleh pasangan yang berkahwin. ${ }^{21}$ Justeru itu, Islam telah menyediakan garis panduan berupa hak dan kewajipan yang mesti dipatuhi dan dilaksanakan pasangan suami isteri agar segala keperluan rumah tangga terlaksana dengan baik, teratur dan sempurna. ${ }^{22}$ Pengabaian hak dan tanggungjawab dalam perkahwinan ini boleh mencetuskan konflik dan masalah dalam rumah tangga dan boleh membawa kepada perceraian. ${ }^{23}$

Hak dan kewajipan dalam rumah tangga dapat dibahagikan kepada tiga iaitu hak suami terhadap isteri, hak isteri terhadap suami dan hak bersama suami isteri. Secara umumnya hak isteri dapat dibahagikan kepada dua iaitu hak yang bersifat kebendaan; mahar dan nafkah, hak yang tidak bersifat kebendaan iaitu pergaulan dan layanan baik dan adil dari suami. Dalam al-Quran,

20 Roziah Omar, "Negotiating Their Visibility".

21 Ahmad Hariri Mohd Saad, Raihanah Hj Azahari, "Pengukuhan Institusi Keluarga Melalui Kawalan Terhadap Perceraian: Analisis Literatur", Jurnal Figh 11 (2014), 175-194.

22 Nur Zahidah, Raihanah Azahari, "Model Keluarga Bahagia Menurut Islam", Jurnal Fiqh 8 (2011), 25-44.

23 Raihanah Azahari, "Factors Contribute to Marital Problems Among Malay Muslim Women: A Case Study in Malaysia", Jurnal Syariah (2008). 
Allah memerintahkan suami untuk bergaul dengan baik kepada isteri. Firman Allah dalam surah al-Nisā' ayat 19:

Maksudnya: "Dan bergaulah kamu dengan mereka (isteri-isteri kamu itu) dengan cara yang baik”. ${ }^{24}$

Manakala hak suami terhadap isteri adalah jauh lebih besar kerana suami adalah pemimpin dan pembimbing kepada isteri. Suami berhak membimbing dan mendidik isteri mengikut syariat Islam. Sebab itu, isteri wajib mentaati suami pada perkara-perkara yang bukan maksiat kepada Allah. Isteri juga dituntut bersikap amanah memelihara keaiban dan kehormatan suami, rumah, harta dan anak-anak termasuk tidak membenarkan orang lain masuk ke dalam rumah melainkan dengan keizinan suami. Isteri juga hendaklah bergaul secara baik dengan suami. ${ }^{25}$

Hak bersama suami isteri pula antaranya adalah hak istimta', hak perwarisan, hak penjagaan anak, hak bergaul dengan baik dan lain-lain lagi.

\section{Kerja-kerja Rumah Tangga Menurut Islam}

Isteri sebagai pengurus rumah tangga adalah jelas dalam Islam. Namun adakah ini bermaksud isteri berkewajipan melakukan kerja-kerja rumah tangga seperti memasak untuk ahli keluarga, membersih dan mengemas rumah, membasuh pakaian dan lain-lain lagi. Dalam hal ini fuqaha mempunyai pandangan yang berbeza mengenai kewajipan ini sama ada suami berhak mendapatkan khidmat isteri untuk melakukan kerja-kerja rumah mahupun melayani keperluan suami?

Jumhur ulama berpandangan seorang suami tidak berhak mendapatkan khidmat seorang isteri mengerjakan kerja-kerja rumah tangga di dalam rumah serta tidak wajib isteri melayani keperluan suami melainkan dengan kemahuan isteri sendiri

24 Tafsir Pimpinan al-Qur'an kepada Pengertian al-Qur'an (Kuala Lumpur: Bahagian Hal Ehwal Islam, Jabatan Perdana Menteri, 1995).

25 Wahbah al-Zuhaylī, al-Fiqh al-Islāmī wa Adillatuh (Damsyiq: Dār al-Fikr, 2002), 6850-6859. 
berbuat demikian tanpa ada paksaan atau mewajibkan kepada isteri. ${ }^{26}$

Mazhab Hanafiyyah: memetik pandangan imam 'Alā' al-Dīn alKasanī dalam kitab Badā ' $i$ ’27; "Sekiranya suami datang membawa makanan yang perlu dimasak lalu isteri enggan memasaknya maka isteri jangan dipaksa berbuat demikian", sebaliknya suami perlu membawa makanan yang sudah siap dimasak.

Tetapi menurut Abū al-Layth situasi demikian hanya terpakai kepada isteri yang tidak dapat menyediakan makanan atau memasak atas sebab-sebab tertentu ataupun jika si isteri dari kalangan orang kenamaan atau bangsawan. Namun jika si isteri mampu melakukan kerja-kerja rumah dan sememangnya dia yang melakukannya sendiri tanpa menggunakan khidmat pembantu, maka dalam situasi ini isteri boleh dipaksa untuk melakukan kerja-kerja rumah tangga. Sebaliknya jika si isteri mempunyai pembantu yang melakukan kerja-kerja tersebut wajib pula bagi suaminya memberikan nafkah dan pakaian atau upah kepada pembantu tersebut.

Mazhab Mālikiyyah: Disebutkan dalam kitab al-Syarh al$\mathrm{Kabir}^{28}$; Wajib bagi suami memberikan khidmat kepada isterinya; (jika suami mempunyai keluasan rezeki), dan isteri (orang yang mempunyai kedudukan/kemuliaan) maka tidaklah menjadi kewajipan isteri untuk berkhidmat (melakukan kerja-kerja rumah). Justeru suami wajib menyediakan pembantu bagi isterinya.Tetapi jika suami tidak berkemampuan, maka isteri hendaklah melakukan kerja-kerja rumah untuk suaminya meskipun isteri seorang yang kaya dan mempunyai kedudukan/kemuliaan, tetapi isteri tidak dituntut melakukan kerja-kerja tersebut untuk tetamunya.

26 'Abd al-Karīm Zaydān, al-Mufașsal fì Ahkām al-Mar'at wa Bayt alMuslim fì al-Syarī'ah al-Islāmiyyah (Bayrūt: al-Risālah, 2000), 302.

27 'Alā' al-Dīn Abī Bakr bin Mas'ūd al-Kasanī, Badā'i ' Sanā' 'i' fì Tartīb al-Syarā' 'i' (Bayrūt: Dār al-Kutub al-'Ilmiyyah, 2003), 150.

28 Syams al-Dīn Muhammad 'Arfa al-Dasūqī, Hasyiyah al-Dasūqū 'alā Syarh al-Kabìr (t.tp: Dār Iḥyā' al-Kutub al-'Arabiyyah, t.th), 510-511. 
Mazhab Syāfi'iyyah: Menurut Abū Isḥāq al-Syīrazī dalam kitab Muhazzab ${ }^{29}$; Tidak wajib bagi seorang isteri memberikan khidmat membuat roti, memasak, membasuh dan sebagainya, kerana yang ditetapkan dalam perkahwinan adalah memberikan khidmat seksual, justeru khidmat selainnya adalah tidak menjadi kewajipan bagi isteri. Pandangan ini juga dipetik oleh Wahbah Zuḥaylī dalam kitabnya. ${ }^{30}$

Mazhab Ḥanābilah: ${ }^{31}$ Tidaklah seorang isteri melayani suaminya dengan menguli tepung, membuat roti, memasak, menyapu dan sebagainya kerana yang ditetapkan dalam perkahwinan adalah memberikan layanan seksual, justeru hal-hal selain itu tidak menjadi kewajipan bagi isteri melakukannya. Bagaimanapun menurut mazhab ini, adalah lebih utama bagi seorang isteri melakukan apa yang menjadi adat kebiasaan.

\section{Perbincangan dalil:}

Ulama yang mewajibkan kerja-kerja rumah tangga kepada isteri berhujah dengan hadis Fatimah RA Menurut mereka sekiranya kerja-kerja rumah adalah tanggungjawab suami, sudah pasti Rasulullah SAW akan meminta Ali RA memenuhi permintaan Fatimah RA dengan menyediakan pembantu kepada Fatimah RA atau mengupah seseorang untuk melakukan kerja-kerja rumah atau meminta Ali RA sendiri yang melakukan kerja-kerja tersebut seperti mana dalam hadis. ${ }^{32}$

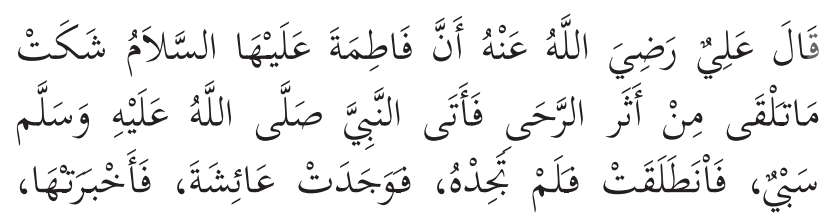

29 Abū Isḥāq al-Syīrazī, al-Muhazzab fì Fiqh al-Imām al-Syafi ‘̄ (Damsyiq: Dār al-Qalam, 1996), 236.

30 Wahbah al-Zuhaylīi, al-Fiqh al-Islāmī wa Adillatuh (Damsyiq: Dār al-Fikr, 2002), 6850.

31 Abū Muhammad 'Abd Allah bin Aḥmad bin Muhammad bin Qudāmah, al-Mughnī (Riyāḍ: Dār 'Alām al-Kutub, 1997), 225.

32 Aḥmad bin 'Alī bin Ḥajr al-'Asqalān̄̄, Fath al-Bārē (Riyāọ: Maktabat al-'Abikan, 2005), 417; 'Abd al-Karīm Zaydān, al-Mufașșal, 305. 


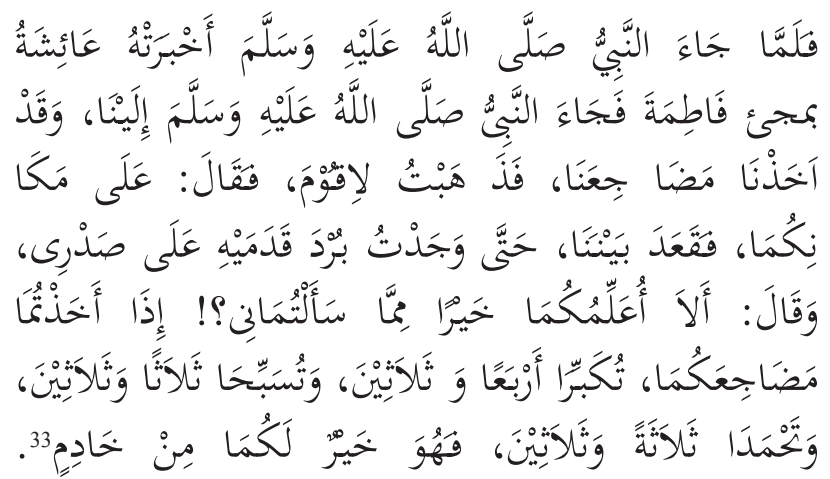

Maksudnya: Ali bin Abi Thalib berkata bahawa Fatimah (isterinya, juga puteri Rasulullah) mengadu sakit tangannya kerana menumbuk (menguli) tepung dan ketika itu pula ada seorang pelayan yang menawarkan dirinya (untuk berkhidmat) kepada Rasulullah. Fatimah datang menemui Rasulullah untuk meminta seorang pembantu tetapi dia tidak berjaya menemui Rasulullah dan hanya bertemu dengan Aisyah. Kemudian Fatimah berpesan kepada Aisyah. Ketika Rasulullah tiba di rumah, Aisyah pun memberitahu baginda tentang kedatangan Fatimah. Ali berkata, lalu Rasulullah pergi ke rumah kami ketika kami tengah berbaring hendak tidur. Maka kami segera bangun, tetapi baginda mencegahnya seraya berkata: "Tetaplah di tempat kalian!" Kemudian Rasulullah duduk di antara kami hingga saya merasakan dinginnya telapak kaki baginda yang menyentuh dada saya. Setelah itu, Rasulullah bersabda: "Inginkah kalian berdua aku ajarkan sesuatu yang lebih baik daripada apa yang kalian minta? Apabila kalian berbaring hendak tidur, maka bacalah takbir (Allahu Akbar) tiga puluh empat kali, tasbih (Subhanallah) tiga puluh tiga kali dan tahmid

33 Al-'Asqalānīi, Fath al-Bārī, Kitāb al-Khumus, Bāb al-Dalīl 'alā 'ana al-Khumus li Nawā'ib Rasūl Allah wa al-Masākin, no. hadith 3009; Kitāb Faḍā'il Aș̣̣āb al-Nabī, Bāb Manāqib 'Alī bin Abī Ṭālib, no. hadith 3578, Kitāb al-Nafaqāh, Bāb 'Amal al-Mar'ah fī Bayt Zawjihā, no. hadith 5163 dan 5164. 


\section{(Alhamdulillah) tiga puluh tiga kali. Sesungguhnya yang demikian itu lebih baik bagi kalian daripada seorang pembantu."}

Tetapi bagi ulama yang tidak mewajibkan kerja-kerja rumah tangga kepada isteri, berpandangan rutin isteri melakukan kerjakerja rumah tangga dalam hadis Fatimah RA tidak membawa maksud kerja-kerja tersebut wajib dilakukan isteri sebaliknya hanya menunjukkan kebiasaan seorang isteri melakukan kerjakerja tersebut dan merupakan sebaik-baik bentuk pergaulan dan pekerti mulia yang ditunjukkan oleh seorang isteri dan puteri Nabi. Oleh yang demikian, memaksakan kerja-kerja rumah tangga kepada seorang isteri sama sekali tidak berasas dan tiada sandaran dalil. $^{34}$

Sebaliknya penetapan kewajipan kerja-kerja rumah tangga di pihak isteri adalah mengambilkira 'urf di sesebuah kawasan atau budaya setempat yang biasanya meletakkan kewajipan mengerjakan kerja-kerja rumah tangga dalam rumah tangga kepada isteri. Ini bermakna penetapan kewajipan ini berkait rapat dengan sosio budaya masyarakat.

Perbincangan ulama di atas menunjukkan tiada kesepakatan dalam meletakkan kewajipan mengerjakan kerja-kerja rumah tangga di pihak isteri mahupun di pihak suami. Kebanyakan ulama termasuk mazhab Shafii mengatakan kerja-kerja rumah tangga bukan kewajipan isteri mahupun hak suami yang dapat dituntut. Bahkan ulama yang mewajibkan isteri melakukan kerjakerja rumah tangga masih memberikan ruang dan keringanan kepada isteri untuk tidak melakukan kerja-kerja ini jika ada sebab yang menghalangnya berbuat demikian. Justeru suami boleh mengupah atau menggaji orang lain untuk melakukan kerjakerja ini jika berkemampuan. Namun bagi mereka yang tidak menggunakan khidmat pembantu tetapi menggunakan khidmat isteri untuk mengerjakan kerja-kerja rumah tangga disebabkan faktor ekonomi atau privasi, kerjasama suami melibatkan diri dengan kerja-kerja rumah tangga sangat penting dan sebaik-baik ihsan dalam perhubungan. Hal ini sangat dianjurkan dalam Islam

34 Al-'Asqalān̄̄, Fath al-Bārī, 417, 'Abd al-Karīm Zaydān, alMufașșal, 305. 
berdasarkan hadis-hadis Rasulullah SAW sebaik-baik teladan dan pedoman para suami;

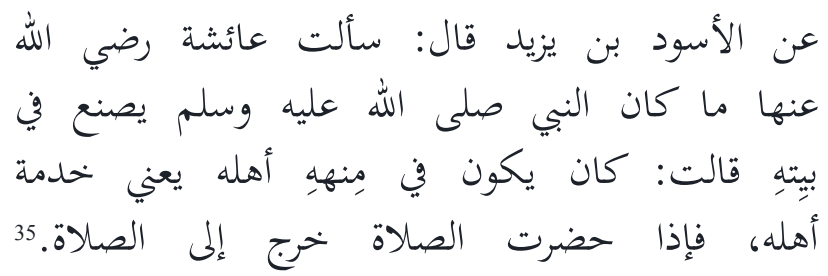

Maksudnya: Daripada al-Aswad bin Yazìd katanya, "Aku bertanya kepada Aisyah: "Apa yang Nabi SAW kerjakan di rumah? Aisyah menjawab: "Baginda sentiasa melayani isterinya iaitu membantu isterinya membuat kerja-kerja rumah. Maka apabila masuk waktu solat, baginda pun keluar untuk solat (ke masjid)".

Hadis di atas menjelaskan Rasulullah SAW turut membantu isterinya melakukan kerja-kerja rumah. Dalam hadis lain diceritakan baginda SAW sendiri membuat kerja-kerja rumah tangga seperti menjahit baju, menampal kasut dan lain-lain. Antaranya;

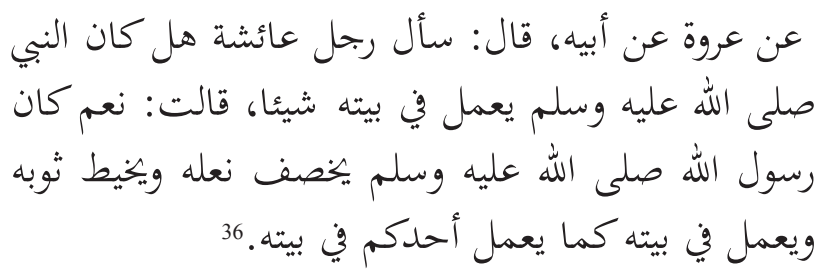

Maksudnya: Daripada Hisyām bin 'Urwah daripada bapanya; "Seorang lelaki bertanya kepada Aisyah: Adakah Nabi SAW melakukan kerja-kerja di rumah”? Aisyah menjawab: "Ya, baginda sendiri menampal kasutnya dan menjahit bajunya dan baginda juga

\footnotetext{
35 Al-'Asqalānī, Fath al-Bārī, Kitāb al-Nafaqāh, Bāb 'Amal al-Mar'ah fī Bayt Zawjihā, Bāb Khidmat al-Rajul fì Ahlih, Bab Kayfa Yakun al-Rajul fĩ Ahlih, no hadith 5165, no. hadith 5824.

36 Al-‘Asqalān̄i, Fath al-Bārī, 476.
} 
membuat pekerjaan di rumah sepertimana yang dibuat oleh orang lelaki (suami) di rumah mereka”.

Berdasarkan hadis-hadis di atas jelas menunjukkan bahawa penglibatan suami dalam kerja-kerja rumah tangga sangat dianjurkan dalam Islam dan merupakan ihssān dalam perhubungan suami isteri yang ditunjukkan Rasulullah SAW yang wajar diteladani oleh para suami.

\section{DAPATAN DAN PERBINCANGAN}

Bahagian ini membincangkan penglibatan suami dalam kerjakerja rumah tangga, faktor-faktor yang dapat dikaitkan dengan penglibatan suami dalam kerja-kerja rumah tangga serta keperluan suami dilibatkan dalam kerja-kerja rumah tangga berdasarkan pandangan dan pengalaman isteri.

\section{Penglibatan Suami dalam Kerja-kerja Rumah Tangga}

Menurut responden suami mereka tidak keberatan melakukan kerja-kerja rumah tangga. Antara kerja-kerja rumah tangga yang dilakukan suami responden adalah seperti mana dalam jadual di bawah;

Jadual 1: Kerja-kerja rumah tangga yang dilakukan suami responden.

\begin{tabular}{|c|c|c|c|c|c|c|c|c|}
\hline Aspek tugasan & $\overline{\widetilde{\sigma}}$ & $\frac{\approx}{\mathscr{N}}$ & $\frac{\mathscr{2}}{\infty}$ & 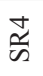 & $\frac{\approx}{\infty}$ & 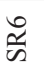 & $\frac{\hat{\alpha}}{\omega s}$ & $\begin{array}{l}\infty \\
\text { a } \\
\infty\end{array}$ \\
\hline Membersih \& mengemas rumah & / & 1 & / & $\mathrm{X}$ & 1 & 1 & $\mathrm{X}$ & $\mathrm{X}$ \\
\hline Membersih kawasan luar rumah & / & / & / & $\mathrm{X}$ & / & / & / & 1 \\
\hline Memasak & $\mathrm{X}$ & / & / & $\mathrm{X}$ & $\mathrm{X}$ & $\mathrm{X}$ & $\mathrm{X}$ & l \\
\hline Membasuh pinggan mangkuk & / & / & / & $X$ & / & / & $\mathrm{X}$ & / \\
\hline Membasuh pakaian & $\mathrm{X}$ & $\mathrm{X}$ & / & $\mathrm{X}$ & $\mathrm{X}$ & l & $\mathrm{X}$ & $\mathrm{X}$ \\
\hline Menggosok baju & $\mathrm{X}$ & 1 & / & $\mathrm{X}$ & $\mathrm{X}$ & 1 & $\mathrm{X}$ & 1 \\
\hline Melipat baju & $\mathrm{X}$ & $\mathrm{X}$ & / & $\mathrm{X}$ & $\mathrm{X}$ & $\mathrm{X}$ & $\mathrm{X}$ & $\mathrm{X}$ \\
\hline Membasuh kereta & / & / & / & $\mathrm{X}$ & 1 & / & / & 1 \\
\hline Membeli keperluan rumah & 1 & / & I & $\mathrm{X}$ & / & l & / & 1 \\
\hline Menjaga/bermain dengan anak & / & / & / & $\mathrm{X}$ & / & / & 1 & 1 \\
\hline $\begin{array}{l}\text { Menghantar/mengambil anak dari } \\
\text { sekolah/rumah pengasuh }\end{array}$ & / & / & / & / & / & / & / & l \\
\hline
\end{tabular}

Sumber: Diubahsuai daripada jawapan temubual responden. 
Berdasarkan jadual 1 di atas, membersih kawasan luar rumah, membasuh kereta, membeli keperluan rumah, menjaga anak di rumah ketika isteri melakukan kerja-kerja rumah, menghantar dan mengambil anak dari sekolah atau rumah pengasuh merupakan kerja-kerja yang dilakukan oleh kesemua suami responden kecuali suami responden 4 yang melakukan kerja menghantar dan mengambil anak dari sekolah sahaja. Ini menunjukkan kerjakerja di luar rumah dan dikerjakan pada waktu tertentu menjadi pilihan suami berbanding kerja-kerja yang menuntut komitmen berterusan seperti melipat baju, membasuh pakaian dan memasak. Kebanyakan kerja-kerja di atas dilakukan dengan kerap oleh suami responden iaitu 5 orang responden mengatakan suami mereka kerap membantu mereka melakukan kerja-kerja rumah sementara 3 orang responden lagi menyatakan suami mereka jarang melakukan kerja-kerja tersebut.

Penglibatan suami dalam pelbagai kerja rumah tangga menunjukkan suami pada hari ni lebih terbuka melalui perkongsian kerja dan kurangnya segregasi kerja mengikut jantina. Suami lebih memahami isteri yang bekerja kerana telah membantu meringankan bebanan ekonomi keluarga. ${ }^{37}$ Dalam konteks kajian ini, terdapat beberapa indikator yang dapat dikaitkan dengan penglibatan suami dalam kerja-kerja rumah tangga seperti di bawah;

\section{i) Sikap}

Sikap bertimbang rasa dan penuh pengertian dalam hubungan suami isteri dituntut dalam ajaran Islam. Menurut responden suaminya melakukan kerja-kerja rumah tangga atas kerelaan sendiri dan menganggap kerja-kerja tersebut merupakan tanggungjawab bersama yang perlu ditunaikan.

"Selalunya suami akan melakukan kerja-kerja rumah tanpa diminta macam masak, kemas rumah, cuci kain dan urus anak". Responden 3

37 Zuraini Jamil, et.al, "Men's Involvement in the Domestic Sphere". 


\section{ii) Budaya keluarga}

Keluarga mempunyai pengaruh besar dalam membentuk sahsiah dan karekter seseorang. Amalan dan kebiasaan melakukan kerjakerja rumah dalam keluarga terdahulu memberi pengaruh kepada suami untuk meneruskan rutin tersebut dalam keluarga barunya.

"Suami saya jenis yang tidak kisah buat kerja-kerja rumah ni sebab katanya dah terbiasa dalam keluarga dia anak sulung, mungkin sebab dulu mentua harap dia saja buat kerja-kerja tu semua". Responden 6

"Kalau bab masak macam boleh semua adik-beradik lelaki suami, kerja-kerja mop lantai segala pun ada juga". Responden 2

\section{iii) Dorongan Isteri}

Perbincangan dan permuafakatan antara suami isteri dalam rumah tangga juga sangat penting. Isteri yang sentiasa memberi galakan dan ruang kepada suami untuk turut serta dalam urusan rumah tangga dapat menarik lebih banyak kerjasama suami. Penglibatan bapa atau suami dalam keluarga bergantung pada sikap dan jangkaan pasangannya. ${ }^{38}$

"Ada juga cakap-cakap dengan suami tentang pembahagian tugas sebab tiada pembantu kan, jadi kena tolong menolong". Responden 8

\section{iv) Kesenggangan dan keperluan}

Penglibatan suami dalam kerja-kerja rumah tangga juga bergantung pada kelapangan suami dan keperluan isteri. Ini bermakna kerjakerja rumah tangga masih menjadi tanggungjawab utama wanita meskipun suami bersedia untuk melibatkan diri dalam kerja-kerja rumah tangga. ${ }^{39}$

38 Dana V. Hiller, William W. Philliber, "The Division of Labor in Contemporary Marriage".

39 Dana V. Hiller, William W. Philliber, "The Division of Labor in Contemporary Marriage".; Zuraini Jamil, et.al, "Men’s Involvement in the Domestic Sphere". 
"Selalunya suami akan melakukan kerja-kerja rumah tanpa diminta macam masak, kemas rumah, cuci kain dan urus anak. Tapi biasanya suami buat pada hujung-hujung minggu atau ikut keperluan". Responden 3

"Kadang tu dia tolong jemur kain dan kalau anakanak ni cerewet mahu dengan aku saja, kadang masak jugala. Tapi kalau dia banyak kerja dan aku tengok dia penat aku sajala yang buat kerja-kerja rumah ni”. Responden 2

"Suami saya biasanya akan memasak atau membeli makanan di luar apabila saya sibuk dan tidak sempat memasak- Responden 5

\section{Keperluan Penglibatan Suami dalam Kerja-kerja Rumah Tangga.}

Dapatan kajian menunjukkan semua responden sepakat mengatakan suami perlu melibatkan diri dalam kerja-kerja rumah tangga. Tugas melakukan kerja-kerja rumah dan mengurus anakanak merupakan tanggunggjawab bersama suami isteri.

"Perkahwinan merupakan sebuah perkongsian, berkongsi hidup, tanggungjawab dan kasih sayang. Kedua-duanya wajib memainkan peranan masingmasing dan saling lengkap melengkapi". Responden 5.

"Buat masa sekarang ini kebanyakan pasangan bekerja tidak seperti dulu hanya lelaki sahaja yang bekerja. Jadi kerja rumah tangga harus dipikul bersama". Responden 2

"Kerja-kerja rumah tangga ini adalah tanggungjawab bersama demi keharmonian rumah tangga agar berkekalan, yang paling penting keikhlasan dan kesabaran". Responden 1

Isteri yang bekerja dan tidak mempunyai pembantu rumah sering berhadapan dengan situasi dan realiti berikut: 


\section{i) Beban kerja yang banyak dan tenaga yang terhad.}

Semua responden dalam kajian ini mengatakan suami perlu membantu isteri melakukan kerja-kerja rumah dan mengurus anak-anak disebabkan mereka memikul beban kerja yang banyak dan tenaga yang terhad.

"Kita masing-masing bekerja dan penat dengan tugas, jadi untuk kurangkan stress isteri, kita saling bantu membantu...sebab kita kan banyak benda mahu fikir...kalau kain belum jemur misalnya sempat lagi fikir mahu masak dan lain-lain..dengan kerja sekolah lagi”. Responden 6

"Suami kenala bantu isteri apa yang patut, kalau tidak kelam kabut juga jadinya kita, lebih-lebih lagi kita ada anak-anak yang masih kecil, mana mahu layan anak, mana mahu masak lagi.." Responden 5

"Kalau boleh semua kerja tu sebolehnya dibahagi bersama suami isteri, memandangkan isteri juga akan berasa penat kerana keluar bekerja..” Responden 3

Wanita yang sudah berkahwin dan yang bekerja di luar rumah terpaksa menggabungkan peranan tradisi mereka sebagai isteri dan ibu dengan peranan sebagai pekerja. Peranan di dalam bidang rumah tangga dan awam ini lazimnya "demanding" dan memerlukan tenaga, masa dan perhatian. ${ }^{40}$ Lantaran itu, isteri yang bekerja sudah tentu mempunyai beban kerja yang banyak dan tenaga yang sangat terhad berbanding dengan isteri yang tidak bekerja untuk melakukan semua kerja-kerja rumah termasuk melayan anak-anak.

Menurut responden penglibatan suami melakukan kerjakerja rumah tangga dapat meringankan beban kerja mereka dan membolehkan mereka mengurus keluarga dengan baik. Ini selaras dengan kajian Shuhairimi dan Huzili (2012) yang mendapati wanita bekerja di Universiti Malaysia Perlis tidak banyak menghadapi masalah dalam rumahtangga kerana suami banyak membantu mengurus keluarga dan tidak terlalu bergantung

40 Fatimah Abdullah, "Wanita dan Pekerjaan", 77-93. 
kepada isteri. ${ }^{41}$ Pembahagian tugas dalam rumah tangga antara suami dan isteri dapat mengurangkan cabaran yang dihadapi oleh isteri yang bekerja dan memberi ruang yang selesa kepada isteri untuk berkhidmat kepada masyarakat. ${ }^{42}$

\section{ii) Gangguan emosi dan perasaan serta membawa konflik dalam rumah tangga.}

Penglibatan suami dalam membantu kerja-kerja rumah sangat diperlukan isteri bagi memastikan tanggungjawab dalam rumah tangga dan kerjaya dapat dilaksanakan dengan baik. Isteri cenderung mengalami gangguan emosi dan perasaan apabila tidak dapat melaksanakan tugasnya dengan baik sebagaimana disebutkan oleh responden;

"Kerja-kerja rumah semua saya buat kecuali ambik anak, suami yang ambil,itu pun payah berpaksa kalau difikir memang stress, kita sama-sama kerja sepatutnya tolong menolongla, tapi bila fikir itu memang tanggungjawab kita (kerja-kerja rumah)kita redha la.." Responden 4

"Memang boleh stress kalau suami tidak bantu kita buat kerja-kerja rumah..yala kita pun manusia biasa juga pandai penat, paling kurang dia tolong jaga anak okla, dapatlah kita buat kerja lain.” Responden 7

"Kita masing-masing bekerja dan penat dengan tugas, jadi untuk kurangkan stress isteri, kita saling bantu membantu...sebab kita kan banyak benda mahu fikir...kalau kain belum jemur misalnya sempat lagi fikir mahu masak dan lain-lain..dengan kerja sekolah lagi”. Responden 6

Wanita yang tidak dapat melaksanakan semua peranan yang sepatutnya dengan baik cenderung mengalami "strain" atau

41 Shuhairimi Abdullah, Huzili Hussin, "Ekspetasi Antara Hasrat dan Realiti Wanita bekerjaya Terhadap Pengurusan Kekeluargaan: Kajian di Universiti Malaysia Perlis", Journal of Human Development and Communication 1 (2012), 107-127.

42 A.M Sultana, Zanariah Noor, "Gender Perspektive of Working Mothers Challenging in Their Family", Australian Journal of Basic and Applied Sciences (2011), 727-731. 
gangguan psikologi, mental dan emosi apabila mereka cuba menggabungkan peranan tradisi sebagai isteri dan ibu dengan peranan sebagai pekerja. ${ }^{43}$

Penglibatan suami membantu isteri melakukan kerja-kerja rumah dan mengurus anak tidak hanya meringankan beban fizikal yang dipikul isteri bahkan mampu memberikan pengaruh positif terhadap emosi isteri yang dikaitkan dengan kepuasan perkahwinan.

"Kita rasa dihargai dan disayangi bila suami tolong kita buat kerja-kerja rumah dan urus anak-anak dan isteri juga akan bertambah sayang pada suami”. Responden 3

"Bila suami bantu, ia beri kesan positif kepada hubungan suami isteri, hubungan bertambah ok sebab kita tidak terlalu terbeban dengan kerja-kerja rumah, dengan mana mahu fikir anak lagi”. Responden 8

Isteri yang mencapai kepuasan perkahwinan adalah isteri yang dapat memenuhi tanggungjawabnya melakukan kerja-kerja rumah dengan bantuan suami. Sebaliknya kurangnya sokongan dan kerjasama daripada suami dalam membantu isteri melakukan kerja-kerja rumah boleh mengundang ketidakpuasan perkahwinan isteri kerana isteri mengalami kesukaran membahagikan tugasan di rumah dan di tempat kerja. Bahkan terdapat satu kajian yang mengaitkan secara khusus kepuasan perkahwinan dengan bagaimana pasangan berbincang dalam soal pembahagian tugasan di rumah, mencari nafkah dan tanggungjawab antara suami isteri. ${ }^{44}$ Kepuasan perkahwinan sangat penting kerana seseorang yang merasa puas dan bahagia dengan perkahwinannya mampu mempengaruhi cara fikir dan tindakannya terhadap diri,

$43 \quad$ Fatimah Abdullah, "Wanita dan Pekerjaan", 77-93.

44 Alpenia Larasati, "Kepuasan Perkawinan pada Istri Ditinjau dari Keterlibatan Suami dalam Menghadapi Tuntutan Ekonomi dan Pembagian Peran dalam Rumah Tangga", Jurnal Psikologi Pendidikan dan Perkembangan 1(3), (2012). 
persekitaran dan masa depannya. ${ }^{45}$ Sebaliknya ketidakpuasan isteri dalam perkahwinan boleh mencetuskan konflik dalam rumah tangga yang jika tidak ditangani dengan cara yang bijak dan betul boleh membawa kepada pengakhiran sebuah perkahwinan. Hal yang sama turut diakui oleh responden dalam kajian ini bahawa suami yang tidak membantu melakukan kerja-kerja rumah boleh mencetuskan konflik dalam rumah tangga. Bahkan suami yang tidak membantu kerja-kerja isteri di rumah adalah penyebab work family-conflict pada wanita bekerja. ${ }^{46}$

Dapatan kajian menunjukkan penglibatan suami dalam kerja-kerja rumah tangga sangat penting dan menjadi keperluan kepada isteri bekerja yang tidak memiliki pembantu rumah. Penglibatan suami dalam kerja-kerja rumah tangga tidak hanya meringankan beban fizikal yang dipikul isteri mahupun membantu mengimbangkan tugas utamanya dalam rumah tangga dan kerjaya sebagaimana yang disebutkan dalam kajian-kajian lepas. Bahkan jauh lebih penting penglibatan suami dapat meringankan beban emosi dan perasaan yang ditanggung isteri. Banyak kajian(Kluwer, Heesink dan Van de Vliert (1996) menyebutkan pasangan suami isteri lebih mudah mengalami konflik berkaitan kerja-kerja rumah tangga berbanding kerja-kerja luar. Pembahagian kerja-kerja rumah tangga antara suami isteri sangat penting kerana berkait rapat dengan kebahagiaan dan kualiti perkahwinan seseorang. Isteri dilaporkan mempunyai kualiti perkahwinan yang tinggi apabila dia berpuas hati dengan pembahagian kerja dalam rumah tangga. ${ }^{47}$ Justeru diharapkan penglibatan suami dalam kerja-kerja rumah tangga menjadi aspek penting yang diteroka dalam kajian-kajian tempatan akan datang bagi mengenal pasti hubungannya dengan kualiti perkahwinan mahupun permasalahan-permasalahan yang

45 Erni Pujia Stuti, Sofia Retnowati, "Kepuasan Pernikahan dengan Depresi pada Kelompok Wanita Menikah yang Bekerja dan yang Tidak Bekerja", Humanitas Indonesian Psychological Journal 1(2) (2014), 1-9.

46 Muniya Altez, Lina Noor Hidayati, "Work Family Conflict pada Wanita Bekerja: Studi tentang Penyebab, Dampak dan Strategi Coping”, Laporan Penilaian (Universitas Negeri Yogyakarta, 2009).

47 Adam M.Galovan et.al, "Father Involvement, Father-Child Relationship Quality and Satisfaction with Family Work: Actor and Partner Influences on Marital Quality", Journal of Family Issues (2013). 
timbul dalam rumah tangga. Fleksibiliti Islam wajar ditonjolkan sebagai satu permis dalam membangunkan rumah tangga yang lebih seimbang dan harmonis. Indikator-indikator yang dikaitkan dengan penglibatan suami dalam kajian ini juga merupakan dapatan awal yang memerlukan kepada kajian yang lebih mendalam dan lebih menyeluruh bagi membangunkan suami sebagai faktor utama keberhasilan keluarga, meskipun dapatan kajian ini tidak dapat digeneralisasikan kepada semua suami di seluruh Malaysia.

\section{KESIMPULAN}

Penglibatan suami dalam kerja-kerja rumah tangga sangat dianjurkan dalam Islam dan merupakan satu bentuk iḥsān dalam perhubungan suami isteri. Ia tidak hanya dapat meringankan beban fizikal yang ditanggung isteri bahkan mampu memberikan pengaruh positif terhadap emosi isteri. Apabila suami melakukan kerja-kerja rumah tangga, maka sebenarnya para suami telah meneladani sebagaimana yang dilakukan Rasulullah SAW. Kerjasama, saling pengertian, tolong-menolong dan toleransi dalam perhubungan rumah tangga pasti dapat membentuk keseimbangan dalam kehidupan berumah tangga.

\section{RUJUKAN}

'Abd al-Karīm Zaydān. Al-Mufașṣal fì Ahkām al-Mar'ah wa Bayt al-Muslim fì al-Syarī'ah al-Islāmiyyah. Bayrūt: al-Risālah, 2000.

A.M Sultana, Zanariah Noor. "Gender Perspektive of Working Mothers Challenging in Their Family". Australian Journal of Basic and Applied Sciences (2011), 727-731.

Abū Muḥammad 'Abd Allah bin Aḥmad bin Muhammad bin Qudāmah. Al-Mughnī. Riyāḍ: Dār Alām al-Kutub, 1997.

Adam M.Galovan, Erin Kramer Holmes, David G. Schramm, Thomas R. Lee. "Father Involvement, Father-Child Relationship Quality and Satisfaction with Family Work: Actor and Partner Influences on Marital Quality". Journal of Family Issues (2013). 
Ahmad Hariri Mohd Saad, Raihanah Azahari. "Pengukuhan Institusi Keluarga Melalui Kawalan Terhadap Perceraian: Analisis Literatur." Jurnal Fiqh 11 (2014), 175-194.

Al-'Asqalān̄̄, Aḥmad bin 'Al̄̄ bin Hajr. Fatḥ al-Bārī. Riyāḍ: Maktabat al-'Abikan, 2005.

Al-Dasūqī, Syams al-Dīn Muḥammad 'Arfa. Hasyiyah al-Dasūqī 'alā Syarh al-Kabīr. t.tp: Dār Iḥyā’ al-Kutub al-'Arabiyyah, t.th.

Al-Kasan̄̄, 'Alā' al-Dīn Abī Bakr bin Mas'ūd. Badā' $i$ ' Șanā'i ' $f \grave{\imath}$ Tartīb al-Syarā' 'i'. Bayrūt: Dar al-Kutub al-'Ilmiyyah, 2003.

Alpenia Larasati. "Kepuasan Perkawinan pada Istri Ditinjau dari Keterlibatan Suami dalam Menghadapi Tuntutan Ekonomi dan Pembagian Peran dalam Rumah Tangga". Jurnal Psikologi Pendidikan dan Perkembangan 11(3), (2012).

Al-Syīrazī, Abū Isḥāq. Al-Muhazzab fì Fiqh al-Imām al-Syāfi' Damsyiq: Dār al-Qalam, 1996.

Al-Zuhaylī, Wahbah. Al-Fiqh al-Islāmī wa Adillatuh. Damsyiq: Dār al-Fikr, 2002.

Amla Salleh, Zahara Aziz, Zuria Mahmud, Abd. Aziz Mahyuddin. "Peranan Bapa dalam Pembangunan Sahsiah Remaja dan Implikasinya terhadap Nilai Kekeluargaan". Jurnal Pendidikan Malaysia 35(2), (2010), 9-17.

Carolyn C. Perrucci, Harry R. Potter and Deborah L. Rhoads. "Determinants of Male Family-Role Performance". Psychology of Women Quarterly 3 (1978).

Dana V. Hiller, William W. Philliber. "The Division of Labor in Contemporary Marriage: Expectations, Perceptions and Perfomance". Social Problem 33(3), (1986).

Erni Pujia Stuti, Sofia Retnowati. "Kepuasan Pernikahan dengan Depresi pada Kelompok Wanita Menikah yang Bekerja dan yang Tidak Bekerja". Humanitas Indonesian Psychological Journal 1(2). 
Fatimah Abdullah. "Wanita dan Pekerjaan:Satu Analisis Konflik Peranan". Akademia (1985), 77-93.

Hesse-Biber, S.N. “The practise ofFeminist In-depth Interviewing”. Dalam Feminist Research Practise. Ed. S. J. N Hesse-Biber, P. L. Leavy (California: SAGE Publications, 2007), 117.

Mohd Anuar Ramli. "Analisis Gender dalam Hukum Islam". Jurnal Fiqh 9 (2012), 137-162.

Mohd Ismail Mustari, Bushrah Basiron. "Faktor Sokongan Individu Terhadap Kecemerlangan Wanita Bekerjaya dan Berumah Tangga". Jurnal Teknologi (Social Sciences) (Johor: UTM Press, 2014), 5-16.

Muniya Altez, Lina Noor Hidayati. "Work Family Conflict pada Wanita Bekerja: Studi tentang Penyebab, Dampak dan Strategi Coping". Laporan Penilaian (Universitas Negeri Yogyakarta. 2009).

Noor Rahamah Abu Bakar. "Wanita Bekerja dan Pengurusan Keluarga." Journal of Society and Space 8 (2012), 155-162.

Nor Aini Idris. Wanita dan Pembangunan Ekonomi (Kuala Lumpur: Dewan Bahasa dan Pustaka, 2008).

Nur Zahidah, Raihanah Azahari, "Model Keluarga Bahagia Menurut Islam". Jurnal Fiqh 8 (2011), 25-44.

Raihanah Azahari, "Factors Contribute To Marital Problems Among Malay Muslim Women: A Case Study In Malaysia”. Jurnal Syariah (2008).

Roziah Omar. "Negotiating Their Visibility: The Lives of Educated and Married Malay Women". Dalam Women in Malaysia. Ed. Roziah Omar, Azizan Hamzah (Kuala Lumpur: Utusan Publication and Distributor Sdn. Bhd. 2003).

Rozumah Baharudin \& Nazli@Nazlina Maliki. "Kebapaan dan Pencapaian Akademik Kanak-kanak Bandar dan Luar Bandar”. Jurnal Pendidik dan Pendidik (1999), 61-83.

Shuhairimi Abdullah, Huzili Hussin. "Ekspetasi Antara Hasrat 
dan Realiti Wanita Bekerjaya Terhadap Pengurusan Kekeluargaan: Kajian di Universiti Malaysia Perlis". Journal of Human Development and Communication 1 (2012), 107-127.

Tafsir Pimpinan al-Qur'an Kepada Pengertian al-Qur'an. Cetakan keenam. Kuala Lumpur: Bahagian Hal Ehwal Islam Jabatan Perdana Menteri, 1995.

Tan Jo-Pei, Rojanah Kahar, Hanina Halimatussaadiah Hamsan. "Keluarga dan Pekerjaan". Dalam Pengantar Keluarga dan Perkahwinan. Ed. Rozumah Baharudin, Rumaya Juhari (Selangor: Penerbit Universiti Putra Malaysia, 2002).

Unit Perancang Ekonomi, Jabatan Perdana Menteri, 2010.

Zuraini Jamil, Tan Bee Piang, Noor Banu Mahadir, M.Sultana Alam. "Men's Involvement In The Domestic Sphere: A Study of Malay Muslim Men in Dual-Career Families inKuala Lumpur and Selangor". Proceedings for the International Conference on Education Islamic Studies and Social Sciences Research (2016) Aceh, Indonesia. 
Jurnal Fiqh, No. 14 (2017) 1-26 